\title{
РОЗРОБКА МАКРОКІНЕТИЧНОЇ МАТЕМАТИЧНОЇ МОДЕЛІ ПРОЦЕСУ БІОЛОГІЧНОЇ ОЧИСТКИ ГАЗОПОДІБНИХ ВИКИДІВ
}

\author{
(C) Г. Ю. Бахарєва, О. В. Шестопалов, С. О. Семенов, Н. О. Букатенко
}

Основне призначення иієї статті - ознайомлення спеціалістів із основами розробки макрокінетичної математичної моделі біологічної очистки газоподібних викидів від органічних та неорганічних токсикантів та одорантів.

Наукові дослідження, які відображено у статті, було виконано згідно планів наукових досліджень кафедри охорони праці та навколишнього середовища та кафедри хімічної техніки та промислової екологї НТУ «ХПІ»

Ключові слова: макрокінетична математична модель, біологічна очистка, питома швидкість окиснення, концентрація, икідлива речовина

The main purpose of this article is familiarization of specialists with the basics of design of macrokinetic mathematical models of biological treatment of gasiform emissions from organic and inorganic toxicants and odorant.

Research, that given in the article, was done according to plans of research of labor and environment protection department and chemical engineering and industrial ecology department of NTU "KhPI"

Keywords: macrokinetic mathematical model, biological treatment, specific rate of oxidation, concentration, harmful substance

\section{1. Вступ}

Газоподібні викиди різного промислового походження за об'ємом, складом шкідливих речовин та їх концентраціями є небезпечним та потужним джерелом забруднення навколишнього середовища. Негативність впливу посилюється ще й тим, що переважно ці джерела забруднення знаходяться у зонах помешкання та життєдіяльності людей. Відомо, що установки біологічної очистки повітря $є$ екологічно чистими, дешевими та простими в експлуатації. Тому, всебічне дослідження процесів біологічної очистки газоподібних викидів $є$ актуальною темою.

\section{2. Постановка проблеми}

Основне значення наведеного у статті дослідження полягає у розробці науково обгрунтованих методик розробки макрокінетичних математичних моделей біологічної очистки газоподібних викидів, як основ для подальших розрахунків проектних параметрів апаратів для біологічної очистки від водорозчинних та неводорозчинних газоподібних забруднень.

Мета даної роботи - винайти наукові основи для проектних розрахунків апаратів біологічної очистки від водорозчинних та нерозчинних у воді забруднень, характерних для викидів багатьох підприємств, які містять багатокомпонентні системи за допомогою розробки макрокінетичних марематичних моделей.

Задачі дослідження - виконання теоретичних та експериментальних досліджень процесів біологічної очистки повітря від забруднюючих речо-вин, визначення поняття макрокінетичної математичної моделі біологічного очищення.

\section{3. Літературний огляд}

Процес біодеструкції газоподібних шкідливих речовин було досліджено низкою вітчизняних та закордонних вчених. Завдяки здібності мікроорганізмів до адаптації, цей універсальний принцип використовується для утилізації широкого спектру забруднюючих речовин органічного походження, а також деяких неорганічних сполук, наприклад, $\mathrm{H}_{2} \mathrm{~S}$, $\mathrm{SO}_{2}$ та $\mathrm{NH}_{3}$. Порівняльний економічний аналіз [1] різних способів очищення газоподібних викидів свідчить про те, що очищення та дезодорація викидів у біофільтрах та біоскруберах вимагає найнижчих капітальних та експлуатаційних витрат. Проте, слід відзначити, що процеси детоксикації таких викидів $\epsilon$ сукупністю взаємопов'язаних процесів, обумовлених скадними біокінетичними реакціями, такими як, наприклад, нітрифікація та денітрифікація [2]. Складність процесів, які відбуваються у біореакторі, ускладнює процедуру моделювання, розрахунку їх апаратурного оформлення та управління [3]. Ці процеси характеризуються жорсткою динамікою (широким рядом констант часу), нелінійністю, змінними з плином часом параметрами та умовами, а також утворенням перехресних сполук тощо [4]. У зв'язку зі специфічністю та токсичністю неорганічних сполук сірки та азоту, виникає необхідність використання у біореакторах імобілізованих [5], а також адаптованих до забруднень штамів мікроорганізмів та їх популяцій [6].

3 урахуванням вищенаведеного, задля розрахунку кінетики складних процесів та конятрукційних параметрів біореакторів, очевидна необхідність комплексного підходу, що включає експериментальне дослідження, розробку на цих засадах методів розробки макрокінетичних марема- 
тичних моделей біологічної очистки газопо-дібних викидів.

\section{4. Дослідження процесу біологічної очистки газоподібних викидів}

Під час проведення досліджень була поставлена така мета: експериментально визначити кінетичні показники біологічної аеробної й анаеробної детоксикації газоподібних викидів, що містять формальдегід, кінетичні показники біологічної детоксикації газоподібних викидів, що містять метан, a також $\mathrm{H}_{2} \mathrm{~S}, \mathrm{SO}_{2}$ та $\mathrm{NH}_{3}$. Ці речовини дуже розповсюджені та містяться окремо або разом у газоподібних викидах багатьох підприємств хімічної, лісохімічної, деревообробної, харчової галузей промисловості, а також у побутових стічних водах. Крім того, ці речовини, які є представниками різних груп сполук (вуглеводні, аліфатичні, сірко- та азотвмісні), піддаються біодеструкції [7].

У лабораторних експериментах встановлювали кінетичні характеристики біотехнологічної детоксикації формальдегіду, розчиненого у воді, у відомому аеробному та розроблювальному анаеробному процесах. Після 8 годин обробки в аеробних умовах ефект очищення від формальдегіду склав $75 \%$, прогнозний термін для досягнення норм ГДК - 20 годин обробки. При обробці в анаеробному процесі $100 \%$ ефект очищення від формальдегіду було досягнуто за 4 години. Максимальна питома швидкість біотахнологічного анаеробного окиснення формальдегіду більш ніж у 6 разів перевищувала значення цього параметру в аеробному процесі [8]. На основі досліджень іноземних вчених та даних власних експериментальних досліджень, було розроблено мікрокінетичну математичну модель зміни конце-нтрації формальдегіду в процесі його усунення 3 газоподібних викидів [9].

Таким чином, на основі досліджень, було зроблено висновок, що для біотехнологічного очищення газоподібних викидів від формальдегіду на стадії регенерації води можна рекомендувати анаеробний процес, як такий, що дозволяє значно пришвидшити доведення екологічно небезпечної концентрації формальдегіду до встановлених норм ГДК. Крім того, при цьому в процесі анаеробної детоксикації формальдегіду можна вести обробку більш концентрованих розчинів, у порівнянні із аеробним процесом, тобто приблизно в 1,5 рази зменшити витрати чистої води на абсорбцію. Експлуатаційні витрати на додатковий реагент - $\mathrm{NaNO}_{3}$ (у якості якого можна використовувати мінеральне добриво), компенсуються виключенням витрат на електроенергію для аерації [10].

Також, у лабораторних експериментальних дослідженнях встановлювали кінетичні характеритики біотехнологічної детоксикації метану та супутніх йому газів $\left(\mathrm{H}_{2} \mathrm{~S}, \mathrm{SO}_{2}\right.$ та $\left.\mathrm{NH}_{3}\right)$ у двосекційному біореакторі 3 шаром, що омивається [11]. В установці, яка моделювала першу (нижню) секцію двосекційного біореактору було визначено кінетичні характеристики біотехнологічної детоксикації розчинених у воді $\mathrm{H}_{2} \mathrm{~S}, \mathrm{SO}_{2}$ та $\mathrm{NH}_{3}$. Експери-ментальні дані свідчать про те, що в діапазоні концентрацій $\mathrm{H}_{2} \mathrm{~S}$ у воді 15-120 мг/дм ${ }^{3}$ швидкість окиснення змінювалася від 12 мг/г за годину в області мінімальних концернтрацій до максимальних значень рівних приблизно 40 мг/г за годину. Близькі та аналогічні за характером результати змін отри-мані і для швидкості окиснення $\mathrm{SO}_{2}$ У воді. У діапазоні концентрацій $\mathrm{NH}_{3}$ у воді $2,5-$ $20 \mathrm{мг/д^{3 }}$ швидкість окиснення змінювалася від приблизно 1,5 мг/Г за годину при мінімальних концентраціях до максимального значення, що дорівнює 5 мг/г за годину. В цілому, виконаний на лабораторній установці експеримент, 3 одержаного рівня швидкостей окиснення, показує технологічну засто-совність біореактору для очищення від $\mathrm{H}_{2} \mathrm{~S}$, $\mathrm{SO}_{2}$ i $\mathrm{NH}_{3}$ [11]. В установці, яка моделювала другу (верхню) секцію двосекційного біореактору було визначено кінетичні характеристики біотехнологічної детоксикації метану 3 газоподібного стану. Після 1 години 15 хвилин обробки газової суміші, що містить метан специфічним мікробіоценозом було досягнуто зниження концентрації метану із 15 об. \% до 0. Максимальна питома швидкість окиснення метану досягла 260 мл/г·год [10].

Таким чином, можна зробити висновок, що за допомогою біотехнологічного методу можна довести екологічно небезпечну концентрацію метану та $\mathrm{H}_{2} \mathrm{~S}$, $\mathrm{SO}_{2} \mathrm{i} \mathrm{NH}_{3}$ у газоподібних викидах до встановлених норм ГДК. Усі дані експериментальних досліджень за результатами статистичної обробки є достовірними.

Докладно усі вище описані експериментальні дослідження із результатами статистичної обробки наведено у [9].

Основи розробки макрокінетичної марематичної моделі, що наведено у цій статті, відтворені на основі даних, отриманих в результаті вище вказаних експериментальних досліджень.

\section{5. Апробація результатів дослідження}

5.1. Поняття макрокінетичної математичної моделі процесу біологічної очистки

Визначаючи питому швидкість окиснення, як кількість шкідливої речовини, яка розкладається одиницею біомаси за одиницю часу, для будь-яких пар значень концентрації та часу, можна записати так [7]:

$$
\frac{\Delta \rho_{\mathrm{i}}}{\Delta \mathrm{t}_{\mathrm{i}}}=-\mu_{0} \mathrm{~V}_{\mathrm{i}}
$$

де $\mu_{0}$ - початкова концентрація біомаси; $\Delta \rho_{\mathrm{i}}=\rho_{\mathrm{i}+1}-\rho_{\mathrm{i}}-$ приріст концентрації; $\Delta \mathrm{t}_{\mathrm{i}}=\mathrm{t}_{\mathrm{i}+1}-\mathrm{t}_{\mathrm{i}}-$ приріст часу; $\mathrm{V}_{\mathrm{i}}-$ питома швидкість окиснення.

Знак «мінус» відображає зменшення концернтрації при позитивній швидкості видалення забруднення.

У граничному переході, при $\Delta \mathrm{t} \rightarrow 0$, одержимо рівняння, що описує процес біологічного очищення в диференційній формі [8]:

$$
\frac{d \rho_{i}}{d t_{i}}=-\mu_{0} V_{t} \text {. }
$$


Тоді, аналітичною формою опису процесу біологічного очищення буде одна із взаємозалежних пар функцій, що задовільняють рівнянню (2) [7]:

$$
\begin{aligned}
& \rho_{\mathrm{t}}=\mathrm{f}_{\rho}(\mathrm{t}) ; \mathrm{V}_{\mathrm{t}}=\mathrm{f}_{\mathrm{v}}(\mathrm{t}) ; \\
& \mathrm{t}_{\rho}=\mathrm{f}_{\mathrm{t}}(\rho) ; \mathrm{V}_{\rho}=\mathrm{f}_{\mathrm{v}}(\rho),
\end{aligned}
$$

де $\mathrm{V}_{\mathrm{t}}$ - залежність питомої швидкості окиснення від часу обробки; $\mathrm{V}_{\rho}$ - залежність питомої швидкості окиснення від концентрації окиснюваної речовини; $\rho_{\mathrm{t}}$ - залежність концентрації окиснюваної речовини від часу обробки; $t_{p}$ - залежність часу обробки від концентрації окиснюваної речовини.

Друга пара взаємозалежних функцій (4) відповідає граничному переходу при $\Delta \rho \rightarrow 0$ та рівноцінному співвідношенню (2) диференційного рівняння [8]:

$$
\frac{\mathrm{dt}_{\rho}}{\mathrm{d} \rho}=-\frac{1}{\mu_{0} \mathrm{~V}_{\rho}}
$$

Вочевидь, що вирази для $\rho_{\mathrm{t}} \mathrm{i} \mathrm{t}_{\rho}$ повинні бути взаємозамінними прямою та зворотньою функціями. Тому, додатковими можливими парами функцій можуть бути [8]:

$$
\begin{gathered}
\mathrm{t}_{\rho}=\mathrm{f}_{\mathrm{t}}(\rho) ; \quad \mathrm{V}_{\mathrm{t}}=\mathrm{f}_{\mathrm{v}}(\mathrm{t}) \\
\rho_{\mathrm{t}}=\mathrm{f}_{\rho}(\mathrm{t}) ; \quad \mathrm{V}_{\rho}=\mathrm{f}_{\mathrm{v}}(\rho)
\end{gathered}
$$

Таким чином, макрокінетична математична модель біологічного очищення $є$ системою двох функцій, що кількісно відображають взаємозалежність концентрації речовини, що видаляється, часу протікання процесу очищення, питомої швидкості деструктурування шкідливої речовини та початкової концентрації біомаси, а також, що задовільняє взаємозв'язки цих же параметрів у диференційній формі [7].

Необхідно підкреслити, що поняття макрокінетичної моделі з необхідністю витікає із визначення найважливішого параметра - питомої швидкості видалення забруднення [7] .

Викладене дозволяє надати розробку макрокінетичної математичної моделі процесу біологічного очищення, як визначення залежностей вигляду $\mathrm{V}_{\rho}, \mathrm{V}_{\mathrm{t}}, \rho_{\mathrm{t}}$ та $t_{p}$, що адекватно описують експериментальні дані та задовільняють диференційному рівнянню (2) або (5) [8].

\section{6. Висновки}

Визначено поняття макрокінетичної математичної моделі біологічного очищення, як системи двох аналітичних функцій, що кількісно від ображають взаємозалежність питомої швидкості деструкції забруднення, його концентрації, часу протікання процесу та початкової концентрації біомаси, а також, що задовольняють взаємозв'язки цих же параметрів в диференційній формі.

Комплекс виконаних теоретичних та експериментальних досліджень, початкові розробки макрокінетичних математичних моделей у сукупності $€$ науковими основами для проектних розрахунків апаратів біологічної очистки від водорозчинних та нерозчинних у воді забруднень, характерних для викидів багатьох підприємств, які містять багатокомпонентні системи.

\section{Лiтература}

1. Gabrieland, D. Technical and economical analysis of the conversion of a ful-scale scrubber to a biotrickling filter for odour control [Text] / D. Gab-rieland, M. A. Deshusses // Water Sciense and Technology. Portland: IWAPublishing. 2004. - Vol. 4. - P. 309-318.

2. Londong, J. Strategies for optimized nitrate reduction with primary denitrification [Text] / J. Lon-dong // Water Sciense and Technology. Portland: IWAPublishing. - 1992. Vol. 5-6. - P. 1087-1096.

3. Sotomayor, O. A. Z. A simulation benchmark to evaluate the perfomance of advanced control techniques in biological wastwater treatment plant [Text] / O. A. Z. Sotomayor, S. W. Park, C. Garc // Brazilian Journal of Chemical Engineering. - 2001. - Vol. 18, Issue 1. doi: 10.1590/s010466322001000100008

4. Wentzel, M. C. Processes and modeling of nitrification-denitrification biological excess phosphorus removal systems - a review [Text] / M. C. Wentzel, G. A. Ekama, G. V. R. Marais // Water Sciense and Technology. Portland: IWAPublishing. - 1992. - Vol. 6. - P. 59-82.

5. Jan, R. Bath experiment on $\mathrm{H}_{2} \mathrm{~S}$ degradation by bacteria immobilised on activated carbons [Text] / R. Jan, V. L. Ng, X. G. Chen, A. L. Geng, W. D. Gouhd, H. Q. Duan, D. T. Ling, L. C. Koe // Water Sciense and Technology. Portland: IWAPublishing. - 2004. - Vol. 4. - P. 299-308.

6. Barbosa, V. L. Hydrogen sulphide removal by activated sludge diffusion [Text] / V. L. Barbosa, D. Dufol, J. L. Callan, R. Sneath, R. M. Stuetz // Water Sciense and Technology. Portland: IWAPublishing. - 2004. - Vol. 4. P. 199-205.

7. Кричковська, Л. В. Процеси та апарати біологічної очистки та дезодорації газоповітряних викидів [Текст]: монографія / Л. В. Кричковська, О. В. Шестопалов, Г. Ю. Бахарєва, К. В. Слісь. - Харків: НТУ «ХПІ», 2013. - 200 с.

8. Кричковська, Л. В. Проектні рішення у розробці апаратів біологічної очистки газоподібних викидів [Текст]: монографія / Л. В. Кричковська, Л. А. Васьковець, І. В. Гуренко та ін.; за ред. проф. Л. В. Кричковської. Харків: НТУ «ХПІ», 2014. - 208 с.

9. Бахарева, А. Ю. Экологически безопасные методы очистки газообразных промышленных выбросов от формальдегида и метана [Текст]: дис... канд. техн. наук: 21.06.01 / А. Ю. Бахарева. - Харьков, 2009. - 210 с.

10. Бахарєва, Г. Ю. Екологічно безпечні методи очистки газоподібних промислових викидів від нормальдегіду та метану [Текст]: автор. дис. ... канд. тех. наук / Г. Ю. Бахарєва. - Київ, 2010. - 20 с.

11. Бахарева, А. Ю. Загрязнение атмосферы городов газообразными выбросами из канали-зационных сетей [Текст] / А. Ю. Бахарева, Е. А. Се-менов // Вісник Національного технічного університету «ХПІ». Збірник наукових праць. Серія: Нові рішення в сучасних технологіях. 2014. - № 7 (1050). - C. 136-141.

\section{References}

1. Gabrieland, D., Deshusses, M. A. (2004). Technical and economical analysis of the conversion of a ful-scale scrubber to a biotrickling filter for odour control. Water Sciense and Technology. Portland: IWAPublishing, 4, 309-318.

2. Londong, J. (1992). Strategies for optimized nitrate reduction with primary denitrification. Water Sciense and Technology. Portland: IWAPublishing, 5-6, 1087-1096.

3. Sotomayor, O. A. Z., Park, S. W., Garcia, C. (2001). A simulation benchmark to evaluate the performance of advanced control techniques in biological wastewater treatment 
plants. Brazilian Journal of Chemical Engineering, 18 (1). doi:10.1590/s0104-66322001000100008

4. Wentzel, M. C., Ekama, G. A., Marais, G. V. R. (1992). Processes and modeling of nitrification-denitrification biological excess phosphorus removal systems - a review. Water Sciense and Technology. Portland: IWAPublishing, 6, 59-82.

5. Jan, R., Ng, V. L., Chen, X. G., Geng, A. L., Gouhd, W. D., Duan, H. Q., Ling, D. T., Koe, L. C. (2004). Bath experiment on $\mathrm{H} 2 \mathrm{~S}$ degradation by bacteria immobilised on activated carbons. Water Sciense and Technology. Portland: IWAPublishing, 4, 299-308.

6. Barbosa, V. L., Dufol, D., Callan, J. L., Sneath, R., Stuetz, R. M. (2004). Hydrogen sulphide removal by activated sludge diffusion. Water Sciense and Technology. Portland: IWAPublishing, 4, 199-205.

7. Krichkovska, L. V., Shestopalov, O. V., Bakhareva, G. Y., Slis, K. V. (2013). Prozesi ta aparati biologichnoy ochistki ta dezodorazii gazopovitryanih vikidiv. Kharkiv: NTU «KhPI», 200.

8. Krichkovska, L. V., Vaskovez, L. A., Gurenko, I. V. et. al. (2014). Proektni rishennya u rozrobzi aparativ biologichnoy ochistki gazopovitryanih vikidiv. Kharkiv: NTU «KhPI», 208.

9. Bakhareva, A. Y. (2009). Ekologicheski bezopasnie metodi ochistki gazoobraznih promishlennih vibrosov ot formaldegida i metana. Kharkiv, 210.

10. Bakhareva, G. Y. (2010). Ekologicheski bezopasnie metodi ochistki gazoobraznih promishlennih vibrosov ot formaldegida i metana. Kiev, 20.

11. Bakhareva, A. Y., Semenov, E. A. (2014). Zagryaznenyie atmosferi gorodov gazoobraznimi vibrosami iz kanalizazionnih setey. Visnik Nazionalnogo tehnichnogo universitetu «KhPI». Zbirnik naukovih praz. Seriya: Novi rishennya $\mathrm{v}$ suchasnih tehnologiyah, 7 (1050), 136-141.

Рекомендовано до публікації д-р техн. наук, професор Дьомін Д. О.

Дата надходження рукопису 27.01.2015

Бахарсва Ганна Юріївна, кандидат технічних наук, доцент, кафедра охорони праці та навколишнього середовища, Національний технічний університет «Харківський політехнічний інститут», вул. Фрунзе, 21, м. Харків, Україна, 61002

E-mail: baharevaann@gmail.com

Шестопалов Олексій Валерійович, кандидат технічних наук, доцент, кафедра хімічної техніки та промислової екології, Національний технічний університет «Харківський політехнічний інститут», вул. Фрунзе, 21, м. Харків, Україна, 61002

E-mail: pheonix_alex@mail.ru

Семенов Свген Олександрович, кандидат технічних наук, доцент, кафедра охорони праці та навколишнього середовища, Національний технічний університет «Харківський політехнічний інститут», вул. Фрунзе, 21, м. Харків, Україна, 61002

E-mail: 982945@gmail.com

Букатенко Наталія Олексіївна, кандидат технічних наук, доцент, кафедра охорони праці та навколишнього середовища, Національний технічний університет «Харківський політехнічний інститут», вул. Фрунзе, 21, м. Харків, Україна, 61002

УДК 629.735.03:004.891.3

DOI: 10.15587/2313-8416.2015.37626

\title{
МЕТОД СИНТЕЗУ ІНТЕЛЕКТУАЛЬНОЇ АВТОМАТИЧНОЇ СИСТЕМИ ДІАГНОСТУВАННЯ ВІБРАЦІЙНОГО СТАНУ ГАЗОТУРБІННОГО ДВИГУНА ГАЗОПЕРЕКАЧУВАЛЬНОГО АГРЕГАТУ
}

\author{
(C) В. С. Гасиджак, М. П. Кравчук, В.В. Шулевка
}

Запропоновано метод синтезу інтелектуальної автоматичної системи діагностування вібраційного стану ГТД на базі інтеграції нечіткої логіки та нейромереж. Досліджено теоретично $i$ експериментально можливості класифікації інтелектуальної автоматичної системи діагностування поточного технічного стану ГТД в прочессі його експлуатації

Ключові слова: газотранспортний двигун, нечітка логіка, вібраційний стан, інтелектуальна автоматична система, нейромережі

In this article a synthesis method of intelligent automation system is presented for vibration state diagnostics of gas turbine engine compressor unit with means of fuzzy logic and neural network. Theoretically and practically were studied intelligent automatic system capabilities of diagnostics of real time technical state of gas transmission engine in use

Keywords: gas transmission engine, fuzzy logic, vibration state, intelligent automatic system, neural networks

\section{1. Вступ}

Газотурбінні двигуни (ГТД) широко використовують у транспортній і енергетичній галузях. В авіації їх використовують як основні і допоміжні рушійні установки; силові установки на морських суднах; в енергогенерувальних агрегатах; вони $\epsilon$ практично основним силовим приводом у газоперекачувальних агрегатах. Ефективність застосування 